\title{
Customary Wedding Ceremony Philoshopy: A Case Study of "Kamajaya-Kamaratih" Style in Onggosoro Borobudur Central Java
}

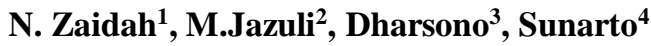 \\ ${ }^{1}$ Universitas PGRI Semarang, Indonesia \\ ${ }^{2,4}$ Universitas Negeri Semarang, Indonesia \\ ${ }^{3}$ Institut Seni Indonesia, Surakarta, Indonesia \\ E-mail: nuningzai@gmail.com, muhjaz61@gmail.com, eyangdharso@gmail.com, \\ sunartounnes@gmail.com
}

\begin{abstract}
This is a case study research based on the custom of Onggosoro Borobudur people in Central Java. This research is going through the multi-disciplinary studies about chronological, historical, meaning and art. This Kamajaya-Kamaratih style wedding ceremony is based on the cultural belief of the community as a myth, therefore, it is taken as the philosophy of marriage of the community. This wedding ceremony is different from the Surakarta and Yogyakarta style. We can see the differences on the sequence of the ceremony, the wedding attire, the make up, the jewelries, the wedding equipments, also the ceremonial order. This is a descriptive-qualitative research with the accurate source of data to be scientifically processed and served. This Kamajaya-Kamaratih style wedding ceremony is the multi-layer entity going through semiotic approach to understand the philosophy contained as the aesthtetic and the expression of the diversity of art in Indonesian culture.
\end{abstract}

Keywords: Philosophy; Ceremony; Kamajaya-Kamaratih

\section{INTRODUCTION}

The Java Island is the world which is being reproduced on many cultural territories, on this range, the fact, fiction, myth, reality, event, sacred, and profane is still undergone, passing or even negotiating each other. One of them is the wedding ceremony in Surakarta and Yogyakarta region which still carries the prestige and the power of culture spreading from the cities until the villages. Both of them is depicting many kinds of style so that it is affected to the manifestation of the cultural procedure which is living on each of the style. The Surakarta style consisted of Solo basahan, Solo putri, and Yogyakarta has Jogya Putri, Paes ageng, Jangan Menir Jogya, Paes Ageng Basahan style.Both of the regions have became the source of inspiration for the wedding ceremony on the Java Island, even the outside of it. Time to time, 
its form and variety becomes the style which is developing along with the advance of the intellectual and mental capacity of human being either in social relations or nature conditions. This happens because of its aesthetic depth of each individual where they put the style of the wedding ceremony so that the modifications of the style can not be avoided. Even though many of the style has been going deep into the tradition which is being done by the people, the source of its wedding tradition is still on the Yogyakarta and Surakarta wedding ceremony. If the Surakarta and Yogyakarta has the rules from the kingdom in both of the region, the wedding ceremony of Onggosoro people in Borobudur, Central Java is still using their own tradition. Using their own tradition based [1] means the defense in integrating the art on its culture also to use the individual, creation, religion needs, soul need and also freedom principles.

The people in Onggosoro Borobudur Central Java have its own style of wedding ceremony called "Kamajaya-Kamaratih". Being called so, it is because of the personification of God Kamajaya and Goddes Kamaratih, the Gods of Love and Marriage [2]. This is what makes it differ from the other style of wedding ceremony. That differences are being seen from the sequence of the ceremony, its origin of existence, and the meaning behind. All of these are the form of the diversity of Indonesian culture specifically the wedding ceremony in Central Java.

\section{RESEARCH METHOD}

This research is using the qualitative approach, which undergoes by collecting the detailed facts in site for bringing deep down to the problem of the research or the phenomenon to bring out the understanding or knowledge. Ratna [3] said that the paradigm of the qualitative research is the videography and the transferability by it means to elaborate and convey the report to the reader in such a detailed and accountable way with the hope of the reader can comprehend what the researcher means by transferring the methodologies so that it can be referred and generalized until being transferred to the other context by considering logical aspect.

This research procedure has the outcome of descriptive data in written or spoken from the participant in the form of description. The data gathered can be words, sentences or pictures which have meaning, facts, principles, systematic and able to spur the comprehension and support in data serving. The qualitative itself is suitable to face the plural reality and multiperspective [4] The result of the research on the customary wedding ceremony is a description in the form of detailed, depth, comprehensive, usefulness narrative leading to the effort of the reparation so that it can ease the researcher to find the depth of the meaning. The interpretative, phenomenologies base perspective is the research on the human world, subjective experience, and the daily life system. This can be seen from the "Kamajaya-Kamaratih" style of wedding ceremony in Onggosoro Borobudur Central Java. The researcher needs the supportive theories to analyze the purpose of the research. The traits analysis used in this research are inductive, building on the power of narrative, the study in the scientific situation, the researcher having the direct contact with the subject in site, holistic thinking to gather the intact comprehension abouth the phenomenon, flexible design, circular, the researcher is the key instrument [5]. The critical and open minded thinking in gathering the data is in the form of open and flexible i.e. in depth interview, role of observing, open document analysis, also the focus group discussion. The tentative in making the wide application about the result of the researcher is because the reality has the multiperspective character. The purposive sampling is being done to find the suitable speaker to the topic which is wanted to be digging in through the in depth interview and focused on the problem of the Javanese-customary wedding ceremony. The practical steps which undergoes by the researcher are a) make the notes in site research; b) make notes; c) 
describe the wedding ceremony by verifying the concept of the result; d) connecting the data in customary wedding ceremony in Onggosoro Borobudur, Central Java; e) compile the constant comparison with other wedding ceremonies in Central Java; f) question the theoretical problem of the wedding ceremony in Onggosoro Borobudur; g) do the coding of the data gathered from in site research; h) developing the theory from the result of the research until being presented.

\section{THE RESULT OF THE RESEARCH AND DISCUSSION}

\subsection{The History of "Kamajaya-Kamaratih" Style Wedding Ceremony in Onggosoro Borobudur Central Java}

The syncretism in Java Island creates the believers which are the local religion believer, the believer believes in ancestral belief which is inherited generations to generations. In Central Java, the Believer Association is many to be found, one of them is the Late Prof. Dr. RM. Wisnoe Wardhana from UNY. He is the founder of association called "Adat Nusantara Asli", an association of many believers to the One and Almighty God or being abbreviated as HPK. HPK “Adat Nusantara Asli” oversees many HPK including "Urip Sejati”. Wisnoe Wardhana is seen as the great teacher because he is inherited the beliefs to his followers until then being developed in Central Java, (interview with Sardjono, 64 y.o.)

The believers of "Urip Sejati" are a cultural belief which is seen as the effort and the rite to harmonize the cosmos to be closed to the God. This believer taught the Javanese mystical "Sangkan paran, Manunggaling Kawula Gusti dan Memayu Hayuning Jagad" means learning that human comes from God's substance and will be back to it, the inseparable unity with God, and the mandatory to saved the world. Those three philosophies are being implemented in their daily life through 9 behaviors called sangang lakuning urip which are individual, bebrayan, economy, politics, science, religions, philosophy, ideology, and mystique.

The believer of "Urip Sejati” lives in Magelang regency being lead by Sardjono the 64 years old man live in Onggosoro Village Mungkid Borobudur, Magelang Regency, central Java. The Kejawen concept "Urip Sejati" based on Sarjono is questioning the living of human in reaching the real and true perfection, which means as a human, to act, behave, work are form of service of dharma as the God's servant. Many rites undergo by this believer one of them is the origin of the wedding ceremony "Kamajaya-Kamaratih" style. This style is being initiated by Wisnoe Wardhana which is taken from the Mahabharata book written in Sanskrit by Begawan Byasa or Vyasa from India, depicted about the love of God Kamajaya and Goddes Kamaratih becomes the fundamental history lof this wedding ceremony. This "Kamajaya-Kamaratih" style becomes the philosophy which carries meaning for the people of Onggosoro Borobudur Central Java.

\subsection{Philosophical Meaning}

\subsubsection{The Meaning of "Kamajaya-Kamaratih" Symbol}

"Kamajaya-Kamaratih" has the meaning as the love symbol, Goddes of fertility, that term is a myth developed in around the people such as Loro-Blonyo, Goddes Sri-Sadana, Rama-Sita, Lingga-Yoni, Tirana-Tirani, Panji Inukertapati-Dewi Sekartaji.All of these are the manifestation 
of the expression of art start from the substance of both elements male - female [6]The Mahabharata Book written in Sanskrit by Begawan Byasa or Vyasa from India tells a story about God Kamajaya and Goddes Kamaratih, it is similar to the visualization myth of God of love from the other region but using the other names and symbols. Taken from the scene of historical story of Kamajaya-Kamaratih shadow puppet is God of Kamajaya becomes the symbol of the perfect male and has the handsome face. Along with his wife, Goddes Kamaratih they are famous with their harmonious and peaceful life, loyal to each other and love each other. God Kamajaya is the ninth son out from ten brothers of God Ismaya and Goddes Senggani. God Kamajaya lives on Cakrakembang Heaven. He has an ultimate weapon which is a magic arrow namely Kyai Pancawisaya. As the "akyan" he is immortal. Kama means desire, lust, apetite, satisfaction, happiness while Jaya means win, superior, main. Therefore, Kamajaya means a main human the Javanese people named it lancuring bawana or lelananging jagad means human which has the authority and responsibility; on the cultural point of view named Pangayom or the protector human.

Goddes Kamaratih is the daughter of God Resi Soma. She is an angel and lives on Kaendran. She is very beautiful, agile; this can be seen from her appearance which is her upturned face and shaking the waist. She is also has the zahidan eyes, has pointed nose, and has beautiful straight hair. Ratih means pure and sincere intimate. Hence, Kamaratih means the human which has pure and sincere intimate as the form of the unity in marriage which fulls of love and affection for the place to peace or happiness. She is doing the rite and isolated herself to gather the mytical power. The power of Goddes Kamaratih is very attracted God Kamajaya, because of the power of their love, the Gods in heaven symbolizes their existence as the God and Goddes of love until the death tears them apart.

\subsubsection{The Meaning of the Wedding Ceremony}

A marriage is a combination from culture and art, [7]. A wedding is a need and the legality of entering the beginning of life for those whom performing it. The needs and the legality has the religion, publicly, self-existence, entertain, liminal process and also communal space aspects. The religion aspect means act or celebration of the act of sequence which tied on to several rules based on custom, religion and government. The marriage ceremony has the effect for publicly, the self-existence can be done by someone with the aim to get the dignities also to show the legal status of a couple so that the people and the environment know that they are existed. The liminal process on the wedding ceremony is the subject feels the ambiguous situation which leads to the suggestion on the new life, the transformation from such condition wishing for the condition that is wanted. The wedding ceremony as the communal space means it is included the community, gathered many various participants, on the whole, building and strengthen the solidarity.

The wedding ceremony undergo as a result of human mental encouragement triggered by the accumulation of the fear also many odds and unsteady experience. The fear can be felt because of the limitation in thinking, while the odd is because the human thinking is still beyond the reach. The marriage ceremony is believed as the effort to avoid something beyond the human reach which can negatively be happened in the marriage. The worry is when there are no harmonious thinking between the couple, the source of money which is unprofitable after the marriage, inequality status, having an imperfect child, death after the marriage, divorce, having the beauty and handsome when the ceremony occurred, or any other symptoms which is not bring the happiness to the couple. The ceremony is wished as once in a lifetime experience, so 
the wedding is being prepared by carefully paying the attention every aspect and avoid in making mistake so that it can create the harmonious show for the next phase of life, also to avoid some disharmonies of the general order of nature which bring the misfortune. Sri Rahayu described that the marriage is a sacred and holy rites, its so important so that there should be done the pre-rites of ceremony to welcome it [8]. This is in line with the statement from G.B.P.H.Yudhaningrat that the wedding ceremony brings the life value, developed and being developed between the people and manifest itself into ceremonial, literature, drama, education, counseling and as an entertainment (G.B.P.H.Yudhaningrat, interview at $12^{\text {th }}$ of December 2017).

\subsubsection{The Philosophy of Customary Wedding Ceremony "Kamajaya-Kamaratih" Style}

The belief of the terms Kamajaya-Kamaratih on the wedding ceremony in Borobudur Central Java based on the cultural stakeholders Sardjono (67 y.o.) is a personification of God of Love which lives on other world and entering on the bride and groom when the ceremony occurs, so that the sequence of the ceremony is different with other wedding ceremony. The philosophy to comprehend the wedding ceremony "Kamajaya-Kamaratih" style in Onggosoro Borobudur is using the semiotic approach to find the aesthetic, because they have the multilayered entities. Every layer in within the ceremony is a very important sign to be interpreted, by iconic, symbolic or indexical way, proven by when the ceremony begin, the couple is using the wedding attire, makeup, jewelry, wedding equipment, ceremonial orders which are different from Surakarta or Yogyakarta wedding ceremony. Based on the modern semiotical pioneer Charles S. Peirce, the relationship between the sign with its reference is differ by 1) Icon, which is the sign refer to the similarity marked;2) Index, is the close existential relation; 3) Symbol, has the conventional meaning [9].

The personification of the God of Love on the "Kamajaya-Kamaratih" style wedding ceremony can be seen on the procession of panggih or the meet of bride and groom which is consisted of bebalangan gantal or throwing the betel nut, mrepeg ponang antigan or breaking the egg and pondhongan (the bride is carried by the groom and the bride's father using their own hand) on this procession is where the guests put their hands up above the head as the symbol which is named sembah akekuncung and cast a geguritan spell or the Javanese poetry. The Javanese poetry is a form of worshipping and the expression of happiness for the marriage of God Kamajaya and Goddes Kamaratih the Gods of Love, interpreted as the Gods have the highest perfection either physically or mentally so that they has indexical and no need to use the pewara panyandra or the metaphor language which is being used by the Master of Ceremony on other wedding ceremony. This procession which makes the "Kamajaya-Kamaratih" Style wedding ceremony differs from the Surakarta and Yogyakarta style wedding ceremony.

The panggih ceremony of this Kamajaya-Kamartih style in Onggosoro is being interpreted as the communication line which is connected in between the families of the bride and the groom to meet the couple which tied them into the legal relationship of husband and wife that is witnessed by the guests. The sequence of the ceremony begins with the reporting of the official report of event by the leader of the believer containing the ability and the willingness both of the couple to take each other also the legal signature from the population and civil agency also the presence some of the witnesses, as the publicly of their legal relationship. All of their life and their identity would be separated, then the couple is entering the top of the procession famously named liminal procession of transition between two statuses, the bride and the groom 
will be ambiguously in between the two worlds which is reality and the world that they wished for. Victor Turner as well as Van Genep separated the procession into three steps, threshold and re-unity separation, liminal or margin and reintegration [10].

\section{CONCLUSION}

"Kamajaya-Kamaratih" is a myth or the communication of message about the prayer and the wish refers to the similarity on comprehending the sign. The communication is manifested as the series of words, spell, in the form of several of things and acts which carries meaning. All of these are in unity, moved by the transcendent powers which are believed as the form of submission. Although the wedding ceremony has the practical traits, it doesn't mean that they allow the penalty for the marriage rules. The marriage is including many of the people as the tying rope of solidarity. The wedding ceremony of "Kamajaya-Kamaratih" style is the depiction of the variety of culture and can be interpreted as the expression of art. The customary wedding ceremony of "Kamajaya-Kamaratih" is becoming the main part of the whole part of the marriage because it made someone felt the transformation from their daily condition and situation. This marriage ceremony in Onggosoro has the multilayer entities, where every layer has a meaning different from the social construction surround them.

\section{REFERENCES}

[1] Rendra, Mempertimbangkan Tradisi. Jakarta: Gramedia, 1983.

[2] Y. B. Mangunwijaya, Burung-burung rantau. Jakarta: Gramedia Pustaka Utama, 1992.

[3] N. K. Ratna, Metodologi Penelitian, Kajian Budaya da Ilmu-ilmu Sosial Humaniora pada Umumnya. Yogyakarta: Pustaka Pelajar, 2010.

[4] H. . Sutopo, Metodologi Penelitian Kualitatif. Surakarta: UNS Press, 2016.

[5] T. R. Rohidi, Metodologi Penelitian Seni. Semarang: Cipta Prima Nusantara, 2011.

[6] J. Sumardjo, Estetika Paradoks. Bandung: Sunan Ambu Press, 2016.

[7] Y. S. Hadi, Seni dalam Ritual Agama. Yogyakarta: Buku Pustaka, 2006.

[8] S. Rahayu and Y. H. Pamungkas, "Arti Simbolis Paes Ageng Masa Hamengkubuwono Ix Tahun," Avatara, E-Journal Pendidik. Sej., vol. 2, no. 3, 2014.

[9] M. De Marinis, The Semiotics of Performance. Bloomington \& Indianapolis: Indiana University Press, 1993.

[10] Y. W. W. Winangun, Masyarakat Bebas Struktur dalam uraian Victor Turner. Liminalitas dan Komunitas. Yogyakarta: Kanisius, 1990. 